\title{
Aid and Gendered Subjectivity in Rural Guatemala
}

\section{Citation}

Moore, Jillian. 2018. Aid and Gendered Subjectivity in Rural Guatemala. Doctoral dissertation, Harvard Medical School.

\section{Permanent link}

http://nrs.harvard.edu/urn-3:HUL.InstRepos:41973535

\section{Terms of Use}

This article was downloaded from Harvard University's DASH repository, and is made available under the terms and conditions applicable to Other Posted Material, as set forth at http:// nrs.harvard.edu/urn-3:HUL.InstRepos:dash.current.terms-of-use\#LAA

\section{Share Your Story}

The Harvard community has made this article openly available.

Please share how this access benefits you. Submit a story.

Accessibility 
Scholarly Report submitted in partial fulfillment of the MD Degree at Harvard Medical School

Date: 15 February 2018

Student Name: Jillian Moore

Scholarly Report Title: Aid and Gendered Subjectivity in Rural Guatemala

Mentor Name and Affiliations: Peter Rohloff, MD, PhD, Department of Medicine, Brigham and Women's Hospital and Wuqu' Kawoq | Maya Health Alliance

Collaborations, with Affiliations: Anita Chary, MD, PhD, Department of Emergency Medicine, Massachusetts General Hospital and Wuqu' Kawoq | Maya Health Alliance; Meghan Farley Webb, PhD, Wuqu' Kawoq | Maya Health Alliance; Anne Kraemer Díaz, Wuqu' Kawoq | Maya Health Alliance 


\section{TITLE: Aid and Gendered Subjectivity in Rural Guatemala}

Jillian Moore, Meghan Farley Webb, Anita Chary, Anne Kraemer Díaz, Peter Rohloff

Purpose: Development discourse has focused on gendered dimensions of poverty, demonstrating how parastatal poverty alleviation programs target women as aid recipients while devaluing their productive and reproductive work. However, seldom analyzed is how privatization of social services and proliferation of non-governmental organizations (NGOs) have impacted women. We explore this in a Guatemalan community.

Methods: Over seven months, ethnographic research was conducted in a rural Guatemalan community. Fifty structured interviews were conducted with local women identified through snowball sampling. These interviews explored resource access, daily responsibilities, and interactions with NGOs, and a household poverty estimation using the Quick Poverty Scorecard. From this initial group, 12 women were invited to participate in longer interviews to explore past interactions with NGOs, gendered household duties and responsibilities, and how each woman allocated her time. Five semi-structured interviews were conducted with local NGO personnel, and content analysis was performed of the websites of 15 local NGOs. All transcripts, field notes, and website text were coded by hand using ground theory.

Results: In this community, women shouldered the burden to provide for their families in times of scarcity, which they did partly through interactions with NGOs. Although these local NGOs discursively commit to 'alternative' development approaches, on the ground they reproduce elements of a gendered neoliberal subjectivity akin to parastatal programs. NGOs additionally configure aid disbursement as gift giving, requiring beneficiaries to assume affective postures of gratitude, and facilitating intrusion into women's lives.

Conclusions: Small NGOs in rural Guatemala govern beneficiaries, particularly women, with a dual subjectivity, simultaneously enforcing participatory labour and conceptualizing aid as a gift, and these relationships are neither participatory nor empowering for the women involved. 


\section{Contribution to the work}

Design: I did the preliminary literature reviews and designed the interview schedules with support from Anne Kraemer Díaz.

Execution: I identified key informants and recruited research participants, in partnership with a local spiritual healer and church leader, as well as a local feminist association. I performed interviews and home visits with help from these individuals who served as research assistants and interpreters. During these interviews and participation observation with NGOs, I kept detailed field notes. I transcribed half of the interviews in Kaqchikel and translated them to English. To transcribe and translate the other half of the interviews, I hired an assistant. Throughout the execution of the study, Anne Kraemer Díaz provided support and answered questions regarding qualitative research methods.

Analysis: I coded all interview transcripts and field notes by hand, with guidance from Peter Rohloff and Anne Kraemer Díaz. I also performed initial content analysis of 15 NGO websites, with secondary analysis performed by Meghan Farley Webb and Anita Chary.

Writing: I primarily wrote the paper with significant support from Peter Rohloff. Revisions and suggestions of references were made by Anita Chary and Meghan Farley Webb. I addressed all revisions by journal editors. Anne Kramer Díaz reviewed the paper before submission.

Roles of others: As specified above. Anne Kraemer Díaz supported me through the design phase. Peter Rohloff, Anita Chary, and Meghan Farley Webb helped with analysis and writing.

Moore J, Webb MF, Chary A, Kraemer Díaz A, Rohloff P. 2017. Aid and Gendered Subjectivity in Rural Guatemala. Journal of Development Studies, 53(12): 2164-2178.

Appendix 1: Accepted Manuscript of the article published by Taylor \& Francis in the Journal of Development Studies on January 23, 2017, available online at: http://www.tandfonline.com/doi/abs/10.1080/00220388.2016.1274397. 


\title{
Aid and Gendered Subjectivity in Rural Guatemala
}

\author{
J. Moore, M. F. Webb, A. Chary, A. Kraemer Díaz \& Peter Rohloff
}

To cite this article: J. Moore, M. F. Webb, A. Chary, A. Kraemer Díaz \& Peter Rohloff (2017) Aid and Gendered Subjectivity in Rural Guatemala, The Journal of Development Studies, 53:12, 2164-2178, DOI: 10.1080/00220388.2016.1274397

To link to this article: https://doi.org/10.1080/00220388.2016.1274397

曲 Published online: 23 Jan 2017.

Submit your article to this journal

Џlll Article views: 174

Q View related articles $\longleftarrow$

View Crossmark data \lceil 


\title{
Aid and Gendered Subjectivity in Rural Guatemala
}

\author{
J. MOORE***, M. F. WEBB**, A. CHARY**,†, A. KRAEMER DÍAZ** \\ \& PETER ROHLOFF**,: \\ *Harvard Medical School, Boston, MA, USA, **Wuqu' Kawoq Maya Health Alliance, Santiago Sacatepéquez, Guatemala, \\ †Department of Anthropology, Washington University School of Medicine, St. Louis, MO, USA, "Division of Global Health \\ Equity, Brigham and Women's Hospital, Boston, MA, USA
}

(Original version submitted June 2016; final version accepted November 2016)

\begin{abstract}
Development discourse has focused on gendered dimensions of poverty, demonstrating how parastatal poverty alleviation programmes target women as aid recipients while devaluing their productive and reproductive work. However, seldom analysed is how privatisation of social services and proliferation of non-governmental organisations (NGOs) have impacted women. We explore this in a Guatemalan community where we find that although $N G O s$ discursively commit to 'alternative' development approaches, on the ground they reproduce elements of a neoliberal subjectivity akin to parastatal programmes. NGOs additionally configure aid disbursement as gift giving, requiring beneficiaries to assume affective postures of gratitude, and facilitating intrusion into women's lives.
\end{abstract}

\section{Introduction}

Since the 1990s, international aid literature has emphasised the unequal burden of poverty on women, often described as the 'feminisation of poverty' (Chant, 2006; Durbin, 1999; Gunewardena \& Kingsolver, 2007). The United Nations' Millennium Declaration and the subsequent Millennium Development Goals promoted gendered approaches to development and poverty alleviation now codified in international aid policy (Chant, 2006; United Nations, 2000). Although this focus on gendered dynamics of poverty is welcome, it has not been unproblematic. Feminist scholars critique how statal and parastatal programmes ${ }^{1}$ foster a gendered development subjectivity that interpellate female aid recipients as rational actors while reinforcing gender inequality (Molyneux, 2006), often through conscripting women in unpaid voluntary community labour to advance development (Neumann, 2013; Silber, 2011), redoubling their responsibilities and reinforcing devaluation of the productive and reproductive work they already perform (Moser, 1993). Gendered approaches to poverty alleviation may also threaten women's social support networks by undermining the communitarian values on which they rest or by provoking resentment from men who are excluded from development projects (Bee, 2011; Farah Quijano, 2009; Neumann, 2013).

Since the proliferation of the civil society sector in the mid-twentieth century, non-governmental organisations (NGOs) have positioned themselves in opposition to 'mainstream' development, construed as statal and parastatal programmes subscribing to macroeconomic approaches and funded by international donor institutions. Instead, NGOs historically relied on independent funding networks and promoted 'alternative' development approaches centred on community organising and conscientisation (Miraftab, 1997; Pieterse, 1998). However, since the 1970s 'mainstream' and 'alternative' development approaches have converged in two important ways. First, 'mainstream' rhetoric has evolved from strictly

Correspondence Address: Peter Rohloff, Division of Global Health Equity, Brigham and Women's Hospital, 75 Francis Street, Boston, MA, 02115, USA. Email: peter@wuqukawoq.org 
emphasising market-based interventions to absorb once 'alternative' methods of engaging communities in 'sustainable' and 'participatory' programmes, adopting what some refer to as a social investment perspective (Jenson, 2010; Pieterse, 1998). Now, as a matter of legitimacy, many 'mainstream' development programmes at least rhetorically promote commitments to participatory action (Schuller, 2012).

Second, 'alternative' development, represented in part by NGOs, has increasingly absorbed once 'mainstream' emphases on institutional professionalisation. In the 1980s, international donor agencies began to experiment with channelling funding through NGOs rather than through statal and parastatal programmes (Edwards \& Hulme, 1996). Suddenly accountable to donors requiring NGOs to monitor and report outcomes, NGOs employed more professional staff, including expatriates and qualified nationals. This professionalisation institutionalised power differentials between NGO staff and beneficiaries along axes of gender, race, and class, undermining some commitments to collaborative, equitable relationships with communities (Miraftab, 1997; Pfeiffer, 2003).

The coalescence of 'mainstream' and 'alternative' development approaches has many implications. On the one hand, statal and parastatal development organisations now impose 'participation' upon beneficiaries, enforcing a neoliberal subjectivity (Foucault, 2008) under which beneficiaries are compelled to view development through a lens of economic rationality and comply with requirements as a matter of investment in self-interest (Molyneux, 2006). This neoliberal subjectivity is well explored in the literature, which we later summarise. Yet what interests us is also the reverse: the gradual transformation of a once 'alternative' NGO sector through absorbing 'mainstream' practices. Using ethnographic data from Guatemala, which has among the highest concentrations of NGOs in the world (Rohloff, Díaz, \& Dasgupta, 2011), we show that NGOs once devoted to 'alternative' development now increasingly require beneficiaries to conform to neoliberal ideals of co-responsibility and compliant participation. However, we find that unlike 'mainstream' organisations whose ideologies NGOs have in many other ways adopted, NGOs do not consider aid a commodity earned through participation (Molyneux, 2006), but rather a gift to be reciprocated.

In his classic theory, Mauss (2000) postulates that in traditional societies, gifting depends upon socially constituted chains of reciprocity. Sahlins (2004) expands this to allow for 'negative reciprocity', or giving when socio-political inequalities are such that gifts cannot be reciprocated. Subsequent scholars note how, under conditions of asymmetric gifting, recipients reciprocate not materially but by acting as deserving subjects who demonstrate gratitude (Bourdieu, 1990; Hattori, 2001; Isik, 2014; Korf, 2007). Invoking these theories, we find that NGOs in Guatemala perceive the aid they transfer as gifts their beneficiaries should affectively reciprocate. NGOs therefore may impose double burdens on beneficiaries who simultaneously adhere to both neoliberal and affective development subjectivities, demonstrating compliance and responsibility to obtain basic necessities and services that are not viewed as earned commodities but gifts to be received in grateful postures.

\section{1. 'New Social Policy' and gendered neoliberal development subjectivity}

To contextualise the preceding discussion, it is important to review recent shifts in Latin American social policy and their gendered implications. In the 1990s, structural adjustment policies had widespread negative impacts on poor households (Pfeiffer \& Chapman, 2010). In response, policy-makers adapted structural adjustment interventions to include explicit anti-poverty measures - such as conditional cash transfer programmes - in a policy synthesis Molyneux (2006) refers to as the 'New Social Policy'. This focus on human capital investments in Latin America signalled a concession that market strategies were not enough to resolve poverty, a departure from structural adjustment policies sufficient enough to lead some scholars to consider this 'social investment perspective' to be post-neoliberal, especially when coupled with a re-emergence of leftist governments in the region (Jenson, 2009, 2010; Staab, 2010). However, evidence is equivocal as to whether these efforts represent true and sustained abandonment of market liberalism (Kaltwasser, 2011; Molyneux, 2009).

Regardless of whether these social investments are considered late neoliberalism or post-neoliberalism, as they coincide with resurging interest in the gendered dynamics of poverty with an increasing focus on the 'feminization of poverty' in the mid 1990s (Chant, 2008), they have radically restructured 
the role of women in the development agenda. Whereas under structural adjustment women were 'shock absorbers' who worked tirelessly to minimise the impacts of regressive social policies on their livelihoods (Sadasivam, 1997), under the New Social Policy, women are the explicit targets of development interventions. Importantly, in this new discourse, though women are imagined as beneficiaries, they actually serve as 'conduits' (Molyneux, 2006) of policies whose aims are elsewhere. For example, Molyneux critiques Mexico's conditional cash transfer programmes whose goals are to improve child nutrition and education. Through these programmes, statal and state-aligned institutions offer funds to female heads-of-households contingent on their completing tasks like bringing children to regular medical check-ups and attending prenatal visits. As such, the programmes require women to make themselves available to be monitored for adherence to requirements intended to serve the welfare of future generations. Similar programmes mandating women's 'participation' have emerged throughout Latin America (Corboz, 2013; Farah Quijano, 2009; Neumann, 2013; Silber, 2011; Smith-Oka, 2013).

Through these anti-poverty programmes that target women and girls, planners and policy-makers have sought to respond to the 'feminisation of poverty' concept present in international development discourse, through which poverty has come to be understood by many as a 'gendered experience' (Molyneux, 2006), drawing attention to gendered inequalities previously ignored. However, as Chant (2008) explains, focusing on 'poverty' in particular may in fact obscure the reality that, whether or not women are more often - or more severely - income-poor than men, due to an unequal and gendered distribution of responsibilities and expectations, women undoubtedly more often shoulder the burdens of household poverty in its many dimensions. Chant (2008) proposes that instead, the term 'feminisation of responsibility and obligation' may more accurately represent the realities many women endure, and perhaps also ensure that interventions inspired by this focus on gendered poverty do not centre on simply 'feminising' anti-poverty programmes, a process that can exacerbate the burdens women shoulder (Molyneux, 2006).

These targeted anti-poverty programmes couch their requirements of women and girls in discourses of 'participation' and 'empowerment', which are meant to foster a sense of self-efficacy and resilience in the face of poverty and relative disempowerment. However, as Gupta and Sharma (2006, p. 284) warn, such discourse may obscure the devolution of state welfare functions onto vulnerable populations, forcing citizens to 'take care of their own development needs' even as states increasingly fail to do so. Furthermore, while these programmes may claim to work towards gender equality, on the ground they seem to be driven not by a moral imperative to secure equality and human rights but rather by an economic utilitarianism based in gendered essentialisms and assumptions (Chant, 2016a, b) in which women serve as conduits (Molyneux, 2006) to achieve economic growth and poverty relief for society in general. In short, the New Social Policy interpellate an idealised female aid recipient, a rational and responsible subject who participates in and complies with the demands of antipoverty programmes in order to guarantee her family's and society's future security (Molyneux, 2006, 2009; Rankin, 2001). We describe this subjectivity as a 'neoliberal' subjectivity, guided by Foucault's (2008) conceptualisation of neoliberal governmentality whereby - independent of any overarching macroeconomic doctrine - individuals are constituted as subjects for whom each social interaction is understood transactionally and as an opportunity for investment.

\subsection{The 'projectification' of aid in Guatemala}

This description of gendered development subjectivity is incomplete, as women not only participate in statal and parastatal programmes but also increasingly encounter NGOs positioning themselves within 'alternative' economies of solidarity, accompaniment, and gender rights (Dacheux \& Goujon, 2012; James, 2010; Maier \& Lebon, 2010; Silber, 2011; Ticktin, 2011). Guatemala is an ideal place to study interactions between communities and NGOs because in recent decades the civil society sector there has proliferated. Although the largest economy in Central America (International Monetary Fund, 2015), Guatemala has one of the lowest tax bases and rates of public social expenditures in the region (The World Bank, 2013). Socioeconomic disparities are stark, with 79 per cent of the Maya population 
living in poverty, as compared to 45 per cent of the non-indigenous population (Cabrera, Lustig, \& Morán, 2015). These disparities are rooted in the exploitation of Maya families, with historical roots in debt peonage on colonial plantations now transformed into informal labour arrangements in contemporary export agriculture, construction, and tourism. Additionally, indigenous Guatemalans have been targets of organised and often gendered violence, most notably during the long civil war (1960-1996). In fact, it was during this war on redistributive ideology that the development enterprise arose in Guatemala: under the Kennedy administration, the United States began to fund counterrevolutionary projects in poor communities at highest 'risk' of identifying with reformist groups (Streeter, 2006). When the civil war ended in 1996, waves of economic restructuring and privatisation of state functions left gaps in the public safety net, which tens of thousands of NGOs have since emerged to fill (Rohloff et al., 2011; Sridhar, 2007).

Scholars in countries with similarly high rates of privatisation and civil society expansion - like Haiti and Uganda - characterise this phenomenon as a 'projectification of aid' (Kristoff \& Panarelli, 2010; Whyte, White, \& Twebaze, 2013). In Guatemala, 'projectification' involves patchworks of overlapping and redundant organisations with short half-lives and shifting missions (Howell \& Pearce, 2001). In this context, the means by which individuals access social services are loosely regulated, and the path to becoming a beneficiary is often convoluted and non-transparent (Chary \& Rohloff, 2015). Some people learn to present themselves as certain types of sufferers to evoke empathy and resource disbursement by aid personnel (James, 2010; Nguyen, 2010; Scherz, 2014). Others creatively leverage social networks, navigating contingencies to access services (Whyte, 2014). These observations hint at an affective subjectivity characterising the relationship between NGOs and beneficiaries at least partially distinct from the neoliberal subjectivity earlier described. We now turn to explore these development subjectivities through a description of how women perceive and interact with NGOs in a Maya community in Guatemala.

\section{Description of research site and methodology}

\subsection{Research site}

Our data come from participant observation and interviews in Chichoy, a community of nearly 4000 people located near Lake Atitlán, a tourist destination in central Guatemala. ${ }^{2}$ Nearly all inhabitants of Chichoy speak primarily Kaqchikel Maya, wear traditional clothing, and self-identify as indigenous. Like many communities in Guatemala, Chichoy has a gendered division of labour. Women generally shoulder domestic duties, though some also work as housekeepers or weavers. Men, having largely abandoned subsistence agriculture, earn wages in the informal sector as day labourers.

Like many towns near Lake Atitlán, Chichoy is saturated with aid interventions. At the time of research, four NGOs worked in Chichoy: an internationally-funded feminist association staffed by local Maya women; a faith-based sponsorship programme from the United States staffed by nonindigenous Guatemalan men from a nearby town; a health clinic run by physicians from the United States and staffed by non-indigenous Guatemalan women from a nearby town; and a Canadian organisation distributing cook stoves through a local Maya politician. Other NGOs conducted intermittent projects in Chichoy, including housing construction and micro-lending programmes. As one estimate of these interactions, virtually all households visited owned improved cook stoves, and nearly half had point-of-use water filters, both technologies provided primarily by NGOs.

\subsection{Research methodology}

For seven months in 2012 and 2013, JM lived full-time in Chichoy, conducting primarily ethnographic research. After four months of living with a family in the community and engaging in participant observation, JM conducted structured interviews with 50 of the approximately 200 female heads-ofhouseholds in Chichoy to better understand resource access, daily responsibilities, and interactions with NGOs. JM identified participants through snowball sampling and through several community 
contacts - including a midwife, church leader, and community health worker - allowing access to multiple social circles in the community. Each structured interview included a household poverty estimation using the Quick Poverty Scorecard, a validated tool used in Guatemala by the microfinance industry (Schreiner \& Woller, 2010). Descriptive statistics were calculated using STATA (College Station, TX); summary results are represented in Table 1.

From the initial group, 12 women representing different social circles and poverty levels were invited to participate in ethnographic interviews to explore findings uncovered in structured interviews. Ethnographic interviews lasted one to two hours and took place in participants' homes during the day when partners and older children were generally absent. These interviews explored interactions with NGOs, gendered duties and responsibilities, and how each woman allocated her time. JM conducted all interviews in the Kaqchikel language, which she speaks fluently, and was accompanied by a local Kaqchikel-speaking female assistant known to the participants. Interviews were digitally recorded with participant permission and transcribed verbatim by a native Kaqchikel speaker. When consent for recording was not given, interviews were documented through handwritten notes taken by JM. Notes and transcripts were coded by hand using grounded theory (Glaser \& Strauss, 1967). Recurrent themes were assigned importance according to frequency of appearance. Initial coding was performed by JM, with subsequent review by AKD and PR.

Aid interactions and resource access were further explored from the perspectives of NGOs. Five semi-structured interviews were conducted with personnel of the four NGOs working in Chichoy to discuss ideologies and experiences. Participants were either foreign volunteers from the United States, or Maya or non-indigenous Guatemalans. In addition, participant observation of interactions between NGO staff and beneficiaries was conducted with three NGOs. Interviews and observations were supplemented by content analysis of websites of 15 NGOs working in the region to explore the discourse used to describe their work to the public. From an online directory of NGOs near Lake Atitlán, every third website was chosen under the headings of 'economic development' and 'health'. These websites are typically in English and oriented towards foreign or national donors and volunteers. From each website, text referring to NGO missions and interactions with beneficiaries, an average of 170 words per site, was coded by hand. JM performed the initial analysis, with subsequent review by $\mathrm{MFW}$ and $\mathrm{AC}$.

As a white woman from the United States, JM regularly took field notes and discussed salient themes in weekly debriefings with co-authors (all non-Guatemalan academics from the United States, all women except for PR) to promote reflexivity and encourage an intersectional exploration of

Table 1. Demographics of structured interview participants $(n=50)$

\begin{tabular}{lc}
\hline Age (years) of participant (mean \pm SD) & $39.7 \pm 12.9$ \\
Preferred language is Kaqchikel, \% & 98 \\
Literate in Spanish, \% & 40 \\
Marital status, \% & 76 \\
$\quad$ Married & 12 \\
Separated & 6 \\
Widowed & 6 \\
Single & $6.4 \pm 2.7$ \\
Household size (mean \pm SD) & $2.6 \pm 2.1$ \\
Children under 13 years (mean \pm SD) & 48 \\
Household income under US\$2/day, \% & 72 \\
Informal economy main income source, \% & 20 \\
Woman earns primary income, \% & 22 \\
Household grows own crops, \% & 48 \\
Household owns water filter, \% & 94 \\
Household owns improved cook stove, \% & $8.8 \pm 3.4$ \\
Hours/day cook/tend fire (mean \pm SD) & $9.0 \pm 6.5$ \\
Hours/week collect biofuel (mean \pm SD) & \\
\hline
\end{tabular}


emerging data ${ }^{3}$. While JM's identity as an upper-class white woman - an identity shared with many aid workers in the area - may have prompted respondents to privilege particular identities in their responses, her extended presence in Chichoy mitigates this tendency. Furthermore, care was taken to communicate that participation was completely voluntary and that the authors were in no way associated with any NGO they might interact with. Although word-of-mouth recruitment may reduce the generalizability of our findings, we attempt to mitigate this risk by reaching multiple social circles and sampling a large proportion of the total population. This research was approved by the Wuqu' Kawoq | Maya Health Alliance Institutional Review Board. JM obtained verbal informed consent for all interviews, both structured and ethnographic. The research was funded by Wuqu' Kawoq | Maya Health Alliance.

\section{Results}

\subsection{The good mother: providing no matter what}

Ethnographic observation and interviews with women elucidate daily routines and responsibilities. As summarised in Table 1, women in Chichoy care for large families, living in households of, on average, six individuals with three children under age 13. Participants described the tasks they assumed as female heads-of-household, including childrearing, cooking, washing, and collecting firewood. Women remarked that these activities filled most of their days, as documented in other studies of indigenous women in Guatemala (Ehlers, 2000; Goldin, 2009; Webb, 2015). For instance, participants reported spending $8.8 \pm 3.4$ hours each day cooking and otherwise tending fires. Those relying on biofuels expended an additional $9 \pm 6.5$ hours each week collecting wood in surrounding hills (Table 1).

Men earned the primary income in 80 per cent of homes (Table 1), reflecting a gendered division of labour characteristic of Maya communities in Guatemala (Bossen, 1984; Ehlers, 2000). Most men performed manual labour for minimal pay in the informal economy, resulting in economic insecurity for many households. Most women interviewed (11/12) reported worrying every day about how to care for their families with limited household finances. This reality was eloquently encapsulated by Soledad, age 32, a mother of seven, when she responded to a question about the roles she and her husband played providing for the family, 'He goes out to look for a job, but what will he earn for the children? He may return with money, or he may not.'

Facing economic insecurity, women (7/12) alluded to a societal expectation in Chichoy that 'good mothers make do' to ensure their families' subsistence. Notably, 20 per cent of the 50 women visited reported earning the primary household income (Table 1). As such, women assumed responsibility to meet family needs not equally shared by male household members (Garrard-Burnett, 2000; Wehr, Chary, Webb, \& Rohloff, 2014). Although Guatemalan women were historically considered 'providers of last resort' (Ehlers, 2000, p. xxxv), today they are primary providers who routinely acquire basic resources their partners increasingly cannot provide. Some women (5/50) found jobs washing clothes or housekeeping. Others (11/50), especially those with young children, wove on back-strap looms in their spare time to produce blouses and bracelets to sell to tourists.

Fiona, age 47 and mother of seven, explained how a mother makes ends meet when facing economic shortfalls, 'If the children have nothing to eat, you find a way. You make tortillas or buy bread ... if [my husband] does not have work, I find a way.' Importantly, a majority of women interviewed (7/12) described 'finding a way' by searching for assistance despite heavy work burdens. For example, when asked about qualities of a 'good' mother, Camila, age 39 and a single mother of three, explained, 'You search for and think of what your children need ... when [a child is in distress] you search and listen for help.' The women illustrate a local understanding of how to be a 'good' mother: dedicating oneself to her children, and not only fulfilling domestic duties but also seeking additional resources necessary for her family's subsistence.

The majority of women interviewed (47/50) reported seeking resources from local aid organisations. In Chichoy, NGOs offered food rations, school scholarships, access to fair trade price structuring and 
weaving supplies, education, and technologies like water filters or cook stoves. When asked about the role of NGOs in her community, Soledad explained, 'Projects provide women with soap, sugar, rice, and milk, which are what children need.' Rosa, age 41 and a single mother of two, similarly opined, 'When a project arrives here we are happy because we may have help. Projects can be good because women do not earn money ... and a project can provide thread for weavings.' Through NGOs, women could secure resources critical to family wellbeing. Half of women (6/12) explicitly stated in ethnographic interviews that the role of NGOs was either to supplement household income or to serve as a woman's income. Given that women in Chichoy viewed accessing aid as a way to 'make do', in the next section we explore how NGO leadership and staff perceived their intended beneficiaries.

\subsection{The good woman: gendered development subjectivity}

The 'feminisation of poverty' and its extension, the 'feminisation of responsibility', emanate not only from 'mainstream' development discourse, but also, as we demonstrate, from 'alternative' development entities like Lake Atitlán NGOs. Just as 'mainstream' development discourse conceptualises women as conduits to improve community welfare, on their websites Lake Atitlán NGOs promoted women as agents to advance community development. All 15 of the websites we examined featured images of Maya women, representing them as virtuous and altruistic subjects in need of empowerment. Two-thirds of the sites displayed images of women with their children. These images occupied over a third of the page, accompanied by text describing women as 'humble', 'strong', and 'invaluable and qualified resource[s]'. One site asserted, 'Mothers are often the primary caregivers and know what their families need most to succeed', implying a maternalist belief that women intuitively understand what their families and children need and are naturally poised to provide it. Another website similarly suggested that women could be activated to transform their communities, once provided the 'right' kind of knowledge, implying that poverty is a property intrinsic to individuals and amenable to selfimprovement: 'With access to the right educational resources and support, Mayan women will lead the way out of this state of poverty.'

Only one-fifth of the websites described underlying causes of poverty, for example: '[through our programs, women] earn a sustainable income, which is beneficial to both their families and communities.' While these three websites acknowledged economic hardship, they did not link Maya families' contemporary situations to extrinsic causes or historical marginalisation and dispossession. Instead, websites represented Maya women as faces of an individualised poverty they could be empowered to escape through education and personal improvement.

On their websites, NGOs recapitulated features of neoliberal development subjectivity more commonly associated with 'mainstream' development, like personal responsibility (12/15), responsiveness to incentives $(8 / 15)$, and submission to surveillance $(5 / 15)$. Websites consistently displayed images of women complying with programme requirements. Three-fifths of the sites emphasised active participation and initiative, for example: 'families we serve are active participants in the program and in their own struggle.' Another site claimed, '[Our projects] allow truly impoverished people to help themselves. We believe in working in partnership with poor Guatemalan people, giving them a hand up, instead of a hand-out.' Furthermore, although many sites described creating 'partnerships' with beneficiaries, they meanwhile discussed empowering beneficiaries to 'help themselves' in their 'own struggles' against poverty.

Interviews with NGO staff deepened our understanding of website themes. On the ground, NGOs expected women to comply with requirements to obtain aid. Most commonly, women had to attend meetings and medical check-ups or complete community labour like collecting trash and sweeping roads. These requirements were often enforced by foreign or non-indigenous Guatemalan staff possessing greater social capital than Maya aid recipients. For example, the faith-based sponsorship NGO required women to attend monthly lectures on childcare, show proof of school attendance and community labour, and submit thank-you notes for donors. The NGO employed non-indigenous Guatemalan men to monitor compliance and distribute aid accordingly. Leandra, age 44, a mother of six, and a beneficiary of this NGO, described her experience with the group: 
We participate in meetings ... and send [thank-you] letters [to sponsors]. If you write the letters, you receive benefits. If you do not, they do not give you benefits ... we go to meetings because we need help. We are attentive to meeting times. We are punctual. You arrive punctually, because if you do not then you do not receive help ... if you do not arrive on time, they tell you that you are irresponsible.

As Leandra describes, because families heavily rely on the items received, women do not see participation or the terms of their participation as choices. Though NGOs encourage participation to 'empower' beneficiaries, on the ground these requirements may actually be disempowering.

In another instance, a health NGO from the United States required patients to regularly present themselves at a clinic for check-ups and to collect medications. In an extreme case, a blind and physically disabled woman missed her appointment. Though she lived near the clinic, the Maya Guatemalan man staffing the clinic would not reach out to her, remonstrating that patients should 'take ownership' of their care and make the effort to show up at the clinic. In this case, the staff member focused on ensuring compliance and obedience rather than considering particularities of the woman's situation and her right to proper care. This example demonstrates how aid can reify socio-political power dynamics whereby poor Maya women are triply marginalised.

NGOs we observed also employed discourses of responsibility and participation to condition beneficiaries to cope in the face of evaporating social safety nets. A Maya woman working for a feminist NGO providing conscientisation and accompaniment to women explained how her institution strived to empower constituents by imparting an ethic of self-sufficiency: 'People should learn to earn their daily bread and not just be here receiving. That will generate more poverty in town because they become accustomed to everything in life being gifted to them, and they will not think about working.' Her fellow staff member, also a Maya woman, agreed: 'We do not hand things out to people because [our organisation] thinks about the community's future.' Staff of this NGO worried that if they freely distributed items, they might perpetuate a dependency culture and preclude women from being productive members of society. By avoiding material relationships with beneficiaries and focusing on reforming individual behaviours, the feminist NGO shifted focus away from extrinsic structural disparities at the root of women's suffering. Even so, women interviewed who regularly participated with this group (4/12) acknowledged the value of conscientisation. Camila explained, 'you start to think about your own life and to value yourself more.' Elena adds, 'You hear other women's testimonies. Now I know that with everything, there is an escape ... but those who do not understand the value of education will not give their scarce time. They only give their time for material goods.' Other women interviewed (2/12) explicitly echoed the importance of receiving material goods, explaining that their partners and families would scold them when they returned home empty-handed. Therefore, though some women valued education and conscientisation, others had to choose between attending such meetings or participating with other groups that more directly and promptly transferred needed material goods to their families.

To make the substance of individual responsibility and compliance more palatable, Lake Atitlán NGOs employed discourses of empowerment, evident in two-thirds of the websites reviewed. For instance, one website noted that their programmes encouraged 'the participation of Mayan women and their empowerment for the exercise and enjoyment of their rights'. Another claimed to 'strengthen the capacities of women for their empowerment', and yet another to 'empower and improve the life of Mayan women.' In interviews, NGO staff (4/5) focused on the 'empowerment' of oppressed women as an important strategy to enable them to thereafter control their situations. However, NGOs circularly defined empowerment as fulfilling conditionalities: a woman who complied with requirements like attendance or labour has been empowered, as through her participation she displayed 'resolve and humility' and 'courage in the face of poverty'. An 'empowered' woman complied with externally imposed conditions.

With these definitions of empowerment, NGOs showed poor insight into how requirements might conflict with local gender roles. For example, in our interviews with women in Chichoy, those most heavily involved with an NGO (4/12) reported abandoning domestic duties to fulfil NGO 
requirements. In these situations, others in their communities could consider the women as neglecting, rather than providing for, their families, especially if their aid seeking did not produce tangible benefits. In such instances, 'empowered' women could find their reputations as respectable women in jeopardy.

\subsection{The good beneficiary: affectivity and aid}

In the preceding section we document how Lake Atitlán NGOs enforce a neoliberal subjectivity commonly associated with 'mainstream' development discourse by idealising responsibility and participation under guises of empowerment. In this section we explore how NGOs also require beneficiaries to assume affective qualities not characteristic of the neoliberal subjectivity.

Female beneficiaries of NGOs we observed were expected to display gratitude for what they received. On one occasion JM visited an NGO from the United States distributing shipments of donated clothing and household items. Donations had just arrived, and news quickly circulated in the community. Nearly 50 women arrived at the office to wait in line, infants strapped to their backs, toddlers clenching their skirts. Some waited for hours to ensure they would not be turned away emptyhanded. The NGO director, a white woman from the United States, was frustrated at how many had shown up. She exclaimed, 'Just last week we gave out gifts for Mothers' Day. Wasn't that enough?' She perceived lining up for this shipment as ingratitude for items distributed the week prior, believing the women should have been satisfied with what they already received.

Some beneficiaries demonstrated gratitude through direct communication with donors in mandatory thank-you letters, which also served to maintain funding streams. Other times beneficiaries expressed gratitude symbolically. For example, women reciprocated through respectful demeanours and deference to staff expertise, which some staff remarked made them feel 'appreciated'. That women felt they must respectfully submit to NGO staff reinforced the position these women occupy at the bottoms of the giving chain and the socio-economic ladder. This obligatory deference also underscores how, through reciprocation, women are interpellated as a new class of person: not merely aid-recipients or subjects of social policy, but humble gift receivers (Bourdieu, 1990; Hacking, 2002).

Women also symbolically displayed gratitude through loyalty. NGO directors and personnel expected constituents to develop exclusive relationships with them, likely rooted in a concern that aid be distributed equitably between households. Accordingly, NGOs discouraged resource shopping seeking aid from multiple organisations - even though this taboo in some ways contradicts both the transitory nature of many NGOs and the resource-searching pragmatism women use to provide for their families. Personnel expressed frustration when beneficiaries aligned with multiple organisations and stigmatised women who did so. A non-indigenous Guatemalan man working for a NGO that provides nutrition supplements to malnourished children related his experience with several families he assisted who also received supplements from other organisations. He bitterly joked that mothers 'must keep malnourished children as a business to receive benefits from all over.' He portrayed women as opportunists, taking advantage of their poverty and the generosity of others to accumulate resources. He not only discounted how women work tirelessly to care for each child, but also failed to recognise gross structural injustices - including worsening unemployment and an absent state welfare apparatus - increasingly forcing families to rely on civil society to get by.

Lastly, in addition to complying with NGO demands of deference and loyalty, some women voluntarily displayed gratitude by allowing unprecedented access to their personal lives. Some women interviewed (4/12) described inviting donors or NGO staff into their homes. In one instance, JM visited Manuela, a young mother of three. They sat in her one-room home containing a bed and two banana crates. Above the bed hung a wooden cross and a framed picture of a white family. When asked about the photo, Manuela beamed, explaining this was the family from the United States who sponsored her daughter. 'They saved her', Manuela exclaimed. She described how, to qualify for sponsorship, each month she wrote thank-you letters, attended monthly meetings, and did community labour. Despite completing these requirements, she felt a moral debt to the donor family and was delighted to display their photo prominently in her private space. JM made a similar visit with Lola, 
age 44 and mother of five. Lola described developing a relationship with a French donor who provided aid to her family. 'In return I named my baby after her', Lola explained.

\subsection{Receiving the gift: engaging and resisting affective subjectivity}

We have demonstrated how Chichoy NGOs place multiple burdens on women by requiring them to simultaneously embody a neoliberal subject and grateful gift recipient. On the one hand, women become entrepreneurs who display diligence and responsibility by participating and complying with requirements. On the other hand, women receive aid as one receives a gift, reciprocating with humility and gratitude. These subjectivities undermine one another: women perform labour for aid, yet they reciprocate for what they receive as if it had been unconditionally given.

Women respond to these competing demands in ways that strategically procure the resources their families require while simultaneously resolving the conflict occasioned by internalising contradicting subjectivities. Some women, like Manuela in the preceding vignette, do so by both completing the tasks required of them and displaying genuine affection towards donors, wholly embodying their roles as humble receivers. However, this ready acceptance of both subjectivities was by no means universal. Some women interviewed, like Leandra in the following vignette, adopted critical stances, expressing frustration with NGO expectations and imagining how a truly 'alternative' form of development might be.

Leandra lives with her six children and husband, a day labourer. She enrolled her twin children in the same faith-based sponsorship NGO that Manuela belonged to. Leandra at first strategically adopted a humble posture like Manuela and attributed her success in receiving aid to this humility. She remembered pleading with a staff member, a non-indigenous Guatemalan man, to take pity on her: 'I said to him, "Sir, please do me a favour. I have these [four children] and the twins who I want to have sponsored to bring my family help." He said, "Well if you are not receiving from another project, then we will see." Satisfied that Leandra was not aligned with another NGO, the man helped her complete the application. Leandra later found out her twins were sponsored.

To receive aid, just like Manuela, Leandra wrote thank-you notes and attended monthly meetings. She described how at meetings each woman was assigned to a labour project by Lionel, a nonindigenous Guatemalan man the NGO employed. Lionel emphasised that by doing voluntary labour, the women demonstrated 'responsibility'. At one meeting Lionel told the women they had no excuse not to participate, 'because women have so much free time in their days.' That month they had to sweep trash and dog faeces from the main road. Leandra recalls Lionel remonstrating: 'You see your poverty. If you are a woman without needs, then do not sweep. But if you are poor, then you sweep.' Although Leandra was grateful for what she received, she was frustrated by what the NGO demanded because she consequently fell behind with domestic duties: 'If we go to a meeting, then our sweeping, dishes, everything remains. When you return home afterwards, you have so much work to do. You cannot do it all ... it is a struggle, but we fight because we need help.'

To receive aid, Leandra presented herself as an ideal aid recipient by complying with requirements, both physical - completing community labour - and affective - presenting herself as a humble subject. Meanwhile, Leandra reflected how an alternative system might not demand so much energy and time. When asked about her ideal development project, Leandra remarked: 'Perhaps there could be a project that wants to help you with no little thing to fulfil. As we are now, it is difficult. We sweep and go to meetings, we do all these things. Maybe a project could just help you, and you actually feel like they help you because there is no grand thing you must do in return.'

This story demonstrates how women like Leandra navigate competing demands placed upon them, strategizing on behalf of their families, meanwhile, through their own form of resistance, attempting to articulate their own subjectivities. In addition, we can see here how the definition of an 'ideal' development project may differ between a development community focused on sustainable poverty relief, and the beneficiaries themselves, worried about their daily subsistence and navigating the web of 'ethical possibilities' open to them in the moment (Scherz, 2014). Lastly, Leandra's story shows how NGOs perpetuate a devaluation of women rooted in a capitalist economy according greater value to commodity production in the public sphere. By insisting 
that women have free time to better their communities in mandated ways, NGOs disregard how women already spend their lives labouring on behalf of 'development', in pursuit of the very causes NGOs claim to support: poverty alleviation, child education, and health. Women accomplish these goals as caregivers, maintaining and enlivening their domestic spaces and fulfilling the tasks central to their moral identities as mothers, all activities beyond the sphere of 'development'.

\section{Conclusions}

Here we explore how NGOs in an aid-saturated Maya community in Guatemala impose two gendered development subjectivities on women. One subjectivity recapitulates elements of a neoliberal subjectivity of statal and parastatal poverty alleviation programmes - emphasising co-responsibility and compliance with participatory requirements - while the other imposes novel affective demands on women derived from conceptualising aid disbursement as gift giving.

We first illustrated how women in Chichoy spend their days performing both productive and reproductive tasks for their households amidst conditions of extreme financial insecurity largely occasioned by a lack of formal employment. Despite many demands on their time, women increasingly serve as household economic providers not of 'last resort' (Ehlers, 2000, p. xxxv), but of 'first resort', creatively navigating their environments, seeking employment, selling weavings, and soliciting assistance from NGOs.

As we learned more about the NGOs working in Chichoy, we found that many emphasised participation and responsibility, the core features of a development subjectivity criticised by feminist scholars for reducing women to 'social policy conduits'(Molyneux, 2006), devaluing their labour as caregivers, and falsely assuming women to be available to 'participate' (Moser, 1993; Neumann, 2013). Furthermore, though some may claim that the participation of women in development projects can support their empowerment and equal rights, on the ground these programmes seem to be based not in a moral imperative to secure women equal rights and participation in society, but rather in a gendered economic utilitarianism, as women and girls are involved in projects with an expectation to labour to benefit society in general (Chant, 2016a, b). Remarkable here is not that these expectations of women exist but rather the quarter from which they emanate. That NGOs - historically promoting 'alternative' development approaches - have come to emulate statal and parastatal poverty alleviation programmes is cause for alarm. Development scholarship is beginning to grapple with the ways that global shifts towards state service privatisation have influenced all levels of development, blurring distinctions between 'mainstream' and 'alternative' ideologies (Gideon, 1998; Li, 2007). For instance, his studies of similarly positioned Maya communities in Guatemala, Jonathan Maupin $(2009,2011)$ documents how, within a 'privatisation vacuum', alternative development organisations have increasingly been pushed 'towards the right', abandoning their communitarian and activist roots.

We then demonstrated how NGOs imposed additional novel burdens on women by reconfiguring aid as a gift. Keeping with principles of 'negative reciprocity' (Sahlins, 2004), gift recipients lacking capital to materially reciprocate instead do so affectively by being grateful. To appropriately demonstrate gratitude for aid demanded that women dedicate their energy and time to cultivate personalistic and deferential relationships with NGOs. Additionally, women had to exhibit affective qualities of a grateful development subject - like exclusivity and loyalty - which directly contradict both the transitory nature of NGOs and the tactical strategies of resource-shopping and 'making-do' which women employ to ensure their families' survival.

In this way, NGOs enforce subjectivities that in fact undermine one another. Under the neoliberal model, women who comply with aid requirements perform labour that is compensated with aid, a merited payment. This theoretically fosters a sense of self-efficacy. However, NGOs in Chichoy govern beneficiaries with a dual subjectivity, simultaneously enforcing participatory labour and conceptualising aid as a gift. Therefore, although women are obligated to 'work', their labour does not entitle them to aid, as they must also affectively reciprocate for what they receive. 
These personalistic relationships are neither participatory nor empowering and in fact parallel historical colonial clientelism in Guatemala whereby Maya peasants received social goods depending on the favour of patrons and employers (McCreery, 1994). Indeed, in contemporary contexts of incompetent state bureaucracy, the poor may strategically leverage clientelistic relationships to obtain basic necessities to survive (Hilgers, 2009). These deep-rooted structures of clientelism and 'negative reciprocity' in Latin America create the upward-directed displays of submission and gratitude feeding the 'affective' development subjectivity we describe (Bourdieu, 1990; Sahlins, 2004).

In Chichoy, clientelism is especially apparent in NGOs employing staff with greater socio-political power to transfer basic goods and services in exchange for labour and deference, as Miraftab (1997) describes in Mexico. Though these charitable transfers meet immediate needs and palliate stings of poverty, to replace state welfare with charity reinforces the misconception that basic needs like food, shelter, education, and adequate medical care are not basic dignities to which citizens are entitled, but rather privileges or favours that the wealthy, each with their own contingencies and politics of exclusion, generously bestow.

In contrast, when people of equal socio-political standing exchange resources, the gratitude and reciprocity exuded may foster feelings of solidarity and connectedness supporting movements towards securing those dignities denied to them (Hilgers, 2009). Accordingly, clientelism may be minimised when groups are run by staff of equal socio-political standing emphasising community organisation and conscientisation, much like the feminist NGO in Chichoy. Others describe how groups engaged in the feminist social movement in Latin America can create and circulate discourses necessary to alter gendered power relations (Alvarez, 1999). However, as we have learned, some women may struggle to value the long-term benefits of community organisation, especially when, given the 'ethical possibilities' open to them in the moment (Scherz, 2014), they may alternatively engage in projects directly distributing goods their families so desperately need.

When we question how NGOs might alter their interactions with communities, questions for additional research arise. Our research has focused on beneficiary perspectives, but we hope to also better understand the positions of the NGO staff that participate in the manufacture of these developmental subjectivities. From our interviews, it is unclear to what degree they truly 'believe' in these ideological frames. It is possible that they function more as 'street-level bureaucrats' (Lipsky, 1980) pragmatic brokers between beneficiaries and upper management and donors - who use adaptive strategies, including resistance, deception, and palliation, to mediate the inevitable implementation gap' between ideal development models and their impure realities (Olivier de Sardan, 2016).

Additionally, we hope to more rigorously explore how relationships between NGOs and their funding networks influence beneficiary experiences. As earlier described, 'alternative' development was historically characterised by bilateral relationships between beneficiaries and donors. As NGOs professionalised, their relationships with beneficiaries radically transformed to become more impersonal; however, the relationships between organisations and their funding networks have not evolved to the same degree, and donors continue to expect organisations to facilitate unmediated access to the lives of beneficiaries, endorsing a unidirectional information transfer that makes spectacles of the struggles of marginalised people. For instance, some describe how NGOs must repeatedly rebrand aid to continue to solicit and mobilise support from donors through images designed to meet consumer expectations (Richey \& Ponte, 2011). Indeed, one way to minimise clientelistic relationships with beneficiaries would be to re-structure NGO relations with communities and popular organisations to act primarily as consultants that are accountable not only to donors, but also, and equally, to beneficiaries who hire them (Miraftab, 1997). Ultimately, through deeper understanding of the sensitivities of NGO staff as well as the impact of donor networks on beneficiary relations, we hope to develop a nuanced understanding of the nature and origins of the affective subjectivity so we may be better poised to suggest a framework for beneficiary engagements that are truly participatory and empowering. 


\section{Acknowledgement}

We thank the people and NGOs of Chichoy for their participation; the staff and patients of Wuqu' Kawoq | Maya Health Alliance, the organisation with which we are all affiliated, for their enthusiasm and engagement in this and other projects; and Dr. Rachel Hall-Clifford for her insightful review. This study was approved by the Wuqu' Kawoq | Maya Health Alliance Institutional Review Board. Replication data and code for this study are available in a public repository at: doi:10.7019/DVN/ ZEBINZ.

\section{Funding}

This work was supported by the Wuqu' Kawoq | Maya Health Alliance.

\section{Disclosure statement}

No potential conflict of interest was reported by the authors.

\section{Notes}

1. Examples of these programmes include state-financed or administered basic health services or conditional cash transfer programmes, as well as multilateral aid packages involving state partnerships with international lending agencies (The World Bank, the International Development Bank) or aid partners (the United States Agency for International Development, United Nations entities, or large multinational organisations).

2. Place and proper names are pseudonyms.

3. We endeavour to use an intersectional approach to data analysis and interpretation, paying attention to gender, ethnicity, place of origin, and socioeconomic class. However we do not analyse sexual identity and expression because in rural Guatemala where we worked these themes are still so taboo as to be essentially unobservable to us.

\section{References}

Alvarez, S. E. (1999). Advocating feminism: The Latin American feminist NGO 'Boom”. International Feminist Journal of Politics, 1, 181-209. doi:10.1080/146167499359880

Bee, B. (2011). Gender, solidarity and the paradox of microfinance: Reflections from Bolivia. Gender, Place \& Culture, 18, 2343. doi:10.1080/0966369X.2011.535298

Bossen, L. (1984). The redivision of labor: Women and economic choice in four Guatemalan communities. Albany, NY: State University of New York Press.

Bourdieu, P. (1990). the logic of practice. Redwood City, CA: Stanford University Press.

Cabrera, M., Lustig, N., \& Morán, H. E. (2015). Fiscal policy, inequality, and the ethnic divide in Guatemala. World Development, 76, 263-279. doi:10.1016/j.worlddev.2015.07.008

Chant, S. (2006). Re-thinking the "feminization of poverty" in relation to aggregate gender indices. Journal of Human Development, 7, 201-220. doi:10.1080/14649880600768538

Chant, S. (2008). The 'feminisation of poverty' and the 'feminisation' of anti-poverty programmes: Room for revision? The Journal of Development Studies, 44, 165-197. doi:10.1080/00220380701789810

Chant, S. (2016a). Galvanizing girls for development? critiquing the shift from 'smart' to 'smarter economics'. Progress In Development Studies, 16, 314-328. doi: 10.1177/1464993416657209

Chant, S. (2016b). Women, girls, and world poverty: Empowerment, equality or essentialism? International Development Planning Review, 38, 1-24. doi:10.3828/idpr.2016.1

Chary, A., \& Rohloff, P. (Eds.). (2015). Privitization and the new medical pluralism: Shifting healthcare landscapes in Maya Guatemala. Lanham, MD: Lexington Books.

Corboz, J. (2013). Third-Way neoliberalism and conditional cash transfers: The paradoxes of empowerment, participation and self-help among poor Uruguayan women. The Australian Journal of Anthropology, 24, 64-80. doi:10.1111/taja.12022

Dacheux, E., \& Goujon, D. (2012). The solidarity economy: An alternative development strategy? International Social Science Journal, 62, 205-215. doi:10.1111/j.14682451.2011.01804.x

Durbin, E. (1999). Towards a gendered human poverty measure. Feminist Economics, 5(2), 105-108. doi:10.1080/ 135457099338003 
Edwards, M., \& Hulme, D. (1996). Too close for comfort? The impact of official aid on non-governmental organizations. World Development, 24, 961-973. doi:10.1016/0305750X(96)00019-8

Ehlers, T. B. (2000). Silent looms: Women and production in a Guatemalan town. Austin, TX: University of Texas Press.

Farah Quijano, M. A. (2009). Social policy for poor rural people in Colombia: Reinforcing traditional gender roles and identities? Social Policy \& Administration, 43, 397-408. doi:10.1111/j.1467-9515.2009.00670.x

Foucault, M. (2008). The birth of biopolitics: Lectures at the Collége de France, 1978-1979. G. Burchell, Trans. New York, NY: Palgrave Macmillian.

Garrard-Burnett, V. (2000). Aftermath: Women and gender issues in post conflict Guatemala. Washington, DC: U.S. Agency for International Development.

Gideon, J. (1998). The politics of social service provision through NGOs: A Study of Latin America. Bulletin of Latin American Research, 17, 303-321. doi:10.1111/j.1470-9856.1998.tb00127.x

Glaser, B. G., \& Strauss, A. L. (1967). The discovery of grounded theory: Strategies for qualitative research. Chicago, IL: Aldine Publishing Company.

Goldin, L. R. (2009). Global Maya: Work and ideology in rural Guatemala. Tucson, AZ: University of Arizona Press.

Gunewardena, N., \& Kingsolver, A. E. (2007). The gender of globalization: Women navigating cultural and economic marginalities. Santa Fe, NM: School for Advanced Research Press.

Gupta, A., \& Sharma, A. (2006). Globalization and postcolonial states. Current Anthropology, 47, 277-307. doi:10.1086/499549

Hacking, I. (2002). Inaugural lecture: chair of philosophy and history of scientific concepts at the Collège de France, 16 January 2001. Economy and Society, 31, 1-14. doi:10.1080/03085140120109222

Hattori, T. (2001). Reconceptualizing foreign aid. Review of International Political Economy, 8, 633-660. doi:10.1080/ 09692290110077610

Hilgers, T. (2009). 'Who is using whom?' Clientelism from the client's perspective. Journal of Iberian and Latin American Research, 15, 51-75. doi:10.1080/13260219.2009.9649902

Howell, J., \& Pearce, J. (2001). Civil society \& development: A critical exploration. Boulder, CO: Lynne Rienner Publishers.

International Monetary Fund. (2015). Regional economic outlook: Western hemisphere. Washington, DC: International Monetary Fund.

Isik, D. (2014). Vakif as intent and practice: Charity and poor relief in Turkey. International Journal of Middle East Studies, 46, 307-327. doi:10.1017/S0020743814000129

James, E. C. (2010). Democratic insecurities: Violence, trauma, and intervention in Haiti. California Series in Public Anthropology. Berkeley, CA: University of California Press.

Jenson, J. (2009). Lost in translation: The social investment perspective and gender equality. Social Politics: International Studies in Gender, State \& Society, 16, 446-483. doi:10.1093/sp/jxp019

Jenson, J. (2010). Diffusing ideas for after neoliberalism: The social investment perspective in Europe and Latin America. Global Social Policy, 10, 59-84. doi:10.1177/1468018109354813

Kaltwasser, C. R. (2011). Toward post-neoliberalism in Latin America? Latin American Research Review, 46, $225-234$. doi:10.1353/lar.2011.0029

Korf, B. (2007). Antinomies of generosity: Moral geographies and post-tsunami aid in Southeast Asia. Geoforum, 38, 366-378. doi:10.1016/j.geoforum.2006.09.005

Kristoff, M., \& Panarelli, L. (2010). Haiti: A republic of NGOs? Peace Brief. 23, 1-3. Retrieved from http://www.usip.org/ publications/haiti-republic-of-ngos

Li, T. (2007). The will to improve: Governmentality, development, and the practice of politics. Durham, NC: Duke University Press.

Lipsky, M. (1980). Street-level bureaucracy: Dilemmas of the individual in public services. New York, NY: Russell Sage Foundation.

Maier, E., \& Lebon, N. (2010). Women's activism in Latin America and the Caribbean: Engendering social justice, democratizing citizenship. New Brunswick, NJ: Rutgers University Press.

Maupin, J. N. (2009). 'Fruit of the accords': Healthcare reform and civil participation in highland Guatemala. Social Science \& Medicine, 68, 1456-1463. doi:10.1016/j.socscimed.2009.01.045

Maupin, J. N. (2011). Divergent models of community health workers in highland Guatemala. Human Organization, $70,44-53$. doi:10.17730/humo.70.1.1w033538861270u6

Mauss, M. (2000). The gift: The form and reason for exchange in archaic societies. New York, NY: W.W. Norton.

McCreery, D. (1994). Rural guatemala: 1760-1940. Redwood City: Stanford University Press.

Miraftab, F. (1997). Flirting with the enemy: Challenges faced by NGOs in development and empowerment. Habitat International, 21, 361-375. doi:10.1016/S0197-3975(97)00011-8

Molyneux, M. (2006). Mothers at the service of the new poverty agenda: Progresa/oportunidades, Mexico's conditional transfer programme. Social Policy \& Administration, 40, 425-449. doi:10.1111/j.1467-9515.2006.00497.x

Molyneux, M. (2009). The 'neoliberal turn' and the new social policy in Latin America: How neoliberal, how new? Development and Change, 39, 775-797. doi:10.1111/j.14677660.2008.00505.x

Moser, C. (1993). Adjustment from below: Low-income women, time, and the triple role in Guayaquil, Ecuador. In S. A. Radcliffe \& S. Westwood (Eds.), Viva: Women and popular protest in Latin America (pp. 173-196). New York, NY: Routledge. 
Neumann, P. J. (2013). The gendered burden of development in Nicaragua. Gender \& Society, 27, 799-820. doi:10.1177/ 0891243213499447

Nguyen, V. (2010). The republic of therapy: Triage and sovereignty in West Africa's time of AIDS. Durham, NC: Duke University Press.

Olivier de Sardan, J. P. (2016). For an anthropology of gaps, discrepancies, and contradictions. Anthropologia, 3(1), $111-131$. doi: $10.14672 /$ ada2016438\%25p

Pfeiffer, J. (2003). International NGOs and primary health care in Mozambique: The need for a new model of collaboration. Social Science \& Medicine, 56, 725-738. doi:10.1016/S02779536(02)00068-0

Pfeiffer, J., \& Chapman, R. (2010). Anthropological perspectives on structural adjustment and public health. Annual Review of Anthropology, 39, 149-165. doi:10.1146/annurev.anthro.012809.105101

Pieterse, J. N. (1998). My paradigm or yours? Alternative development, post-development, reflexive development. Development and Change, 29, 343-373. doi:10.1111/14677660.00081

Rankin, K. (2001). Governing development: Neoliberalism, microcredit, and rational economic woman. Economy and Society, 30, 18-37. doi:10.1080/03085140020019070

Richey, L. A., \& Ponte, S. (2011). Brand aid: Shopping well to save the world. Minneapolis, MI: University of Minnesota Press.

Rohloff, P., Díaz, A. K., \& Dasgupta, S. (2011). "Beyond development": A critical appraisal of the emergence of small health care non-governmental organizations in rural Guatemala. Human Organization, 70, 427-437. doi:10.17730/humo.70.4. q616gr1p6x6x032q

Sadasivam, B. (1997). The impact of structural adjustment on women: A governance and human rights agenda. Human Rights Quarterly, 19, 630-665. doi:10.1353/hrq.1997.0031

Sahlins, M. D. (2004). Stone age economics. New York, NY: Routledge.

Scherz, C. (2014). Having people, having heart: Charity, sustainable development, and problems of dependence in central uganda. Chicago, IL: The University of Chicago Press.

Schreiner, M., \& Woller, G. (2010). A simple poverty scorecard for Guatemala. Retrieved from http://www.microfinance.com/ English/Papers/Scoring_Poverty_Guatemala_EN_2006.pdf

Schuller, M. (2012). Killing with kindness: Haiti, international aid, and NGOs. New Brunswick, NJ: Rutgers University Press.

Silber, I. C. (2011). Everyday revolutionaries: Gender, violence, and disillusionment in postwar El Salvador. New Brunswick, NJ: Rutgers University Press.

Smith-Oka, V. (2013). Shaping the motherhood of indigenous Mexico. Nashville, TN: Vanderbilt University Press.

Sridhar, A. (2007). Tax reform and promoting a culture of philanthropy: Guatemala's "Third Sector" in an era of peace. Fordham International Law Journal. 31, 186-229. Retrieved from http://ir.lawnet.fordham.edu/ilj/vol31/iss1/3

Staab, S. (2010). Social investment policies in Chile and Latin America: Towards equal opportunities for women and children? Journal of Social Policy, 39, 607-626. doi:10.1017/S0047279410000243

Streeter, S. M. (2006). Nation-building in the land of eternal counter-insurgency: Guatemala and the contradictions of the alliance for progress. Third World Quarterly, 27, 57-68. doi:10.1080/01436590500368974

The World Bank. (2013). Towards better expenditure quality: Guatemala public expenditure review. Washington, DC: The World Bank.

Ticktin, M. I. (2011). Casualties of care: Immigration and the politics of humanitarianism in France. Berkeley, CA: University of California Press.

United Nations. (2000). United Nations millennium declaration. Retrieved from http://www.un.org/millennium/declaration/ ares552e.htm.

Webb, M. F. (2015). Yojkanäj wawe': Kaqchikel migrants' wives under surveillance (Unpublished doctoral dissertation). University of Kansas, Lawrence.

Wehr, H., Chary, A., Webb, M. F., \& Rohloff, P. (2014). Implications of gender and household roles in indigenous Maya communities in Guatemala for child nutrition interventions. International Journal of Indigenous Health, 10, 100-113. doi:10.18357/ijih.101201513196

Whyte, S. R. (2014). Second chances: Surviving AIDS in Uganda. Durham, NC: Duke University Press.

Whyte, S. R., White, M. A., \& Twebaze, J. (2013). Therapeutic clientship: Belonging in Uganda's projectified landscape of AIDS care. In J. Biehl \& A. Petryna (Eds.), When people come first: Critical studies in global health (pp. 140-165). Princeton, NJ: Princeton University Press. 